\title{
To Study the Effect of Weed Observation Practices in Transplanted Kodomillet (Paspalum scrobiculatum L.)
}

\author{
Yendrembam Bebila Chanu ${ }^{1 *}$, S. Jawahar ${ }^{2}$, K. Nandini Devi ${ }^{1}$, \\ Priyanka Irungbam ${ }^{1}$ and Jamkhogin Lhungdim ${ }^{1}$
}

${ }^{1}$ Department of Agronomy, College of Agriculture C. A. U, Imphal-795004, India

${ }^{2}$ Department of Agronomy, Annamalai University, Tamil Nadu-608002, India

*Corresponding author

\section{Keywords}

Butachlor,

Bispyribac-sodium,

Kodo millet, Weed

observation

\section{Article Info}

Accepted:

07 October 2018

Available Online:

10 November 2018

\section{A B S T R A C T}

A field experiment was carried out at the Experimental Farm, Department of Agronomy, Faculty of Agriculture, Annamalai University, Annamalainagar, Tamil Nadu, India during Kharif season (June-October) 2014 to study the effect of weed observation practices in transplanted kodo millet (Paspalum scrobiculatum L.). The experiment consists of six viz., $\mathrm{T}_{1}$ - Unweeded control, $\mathrm{T}_{2}$ - Hand weeding on $20^{\text {th }}$ and $40^{\text {th }}$ days after transplanting (DAT), $\mathrm{T}_{3}$ - Pre - emergence application of Butachlor @ $1.5 \mathrm{~kg}$ a.i / ha on $3 \mathrm{DAT}, \mathrm{T}_{4}$ - Pre emergence application of Pretilachlor @ $0.5 \mathrm{~kg}$ a.i/ ha on 3 DAT, $\mathrm{T}_{5}$ - Post - emergence application of 2, 4, D- Na Salt @ $0.75 \mathrm{~kg}$ a.i/ha on 20 DAT and $\mathrm{T}_{6}$ - Post - emergence application of Bispyribac-Sodium @ $20 \mathrm{~g} / \mathrm{ha}$ on 20 DAT. The experiment was lay out in randomize block design with four replications. The results revealed that hand weeding on 20 and 40 DAT $\left(\mathrm{T}_{2}\right)$ recorded the least individual weed count of $1.37 \mathrm{~m}^{-2}$ of $C$. rotundus, $1.93 \mathrm{~m}^{-2}$ of B. capensis and $2.77 \mathrm{~m}^{-2}$ of C. rotundus, $2.62 \mathrm{~m}^{-2}$ of B. capensison 30 and 60 DAT. Similarly the hand weeding on 20 and 40 DAT $\left(\mathrm{T}_{2}\right)$ controlled most of the weeds and recoded the least total weed count of $7.63 \mathrm{~m}^{-2}$ and $13.58 \mathrm{~m}^{-2}$ on 30 and 60 DAT. Among the treatments, hand weeding on 20 and 40 DAT $\left(\mathrm{T}_{2}\right)$ was superior and recorded the lowest weed biomass of $4.83 \mathrm{~kg} \mathrm{ha}^{-1}$ and $7.79 \mathrm{~kg} \mathrm{ha}^{-1}$ on 30 and 60 DAT. At 30 and 60 DAT, the highest weed control index of 69.41 and 62.56 per cent were recorded from the treatment of hand weeding on 20 and 40 DAT. Among the various herbicide tested, hand weeding on 20 and 40 DAT $\left(\mathrm{T}_{2}\right)$ recorded the lowest nutrient removal by weeds of 15.64, 7.64 and $13.94 \mathrm{~kg} \mathrm{~N}, \mathrm{P}_{2} \mathrm{O}_{5}$ and $\mathrm{K}_{2} \mathrm{O} \mathrm{ha}^{-1}$. The highest $\mathrm{B}: \mathrm{C}$ ratio (2.41) was recorded from the treatment $\mathrm{T}_{6}$ i.e. post emergence application of bispyribac sodium @ 20 $\mathrm{g} \mathrm{ha}^{-1}$ on 20 DAT. Thus, application of bispyribac sodium @ $20 \mathrm{~g} \mathrm{ha}^{-1}$ on 20 DAT holds immense potentiality to control the all types of weeds, boost the productivity and profitability of transplanted kodo millet.

\section{Introduction}

The transformation of agriculture to more productive systems has often been accompanied by increased production of a fewer crop species. Concurrently, the area and production of a great diversity of traditional crops have declined. Yet in many parts of the world, these traditional crops play an important role in maintaining stable and 
sustainable forms of agriculture. One such traditional group of cereal crops is the small millets or minor millets. The grains of small millets, being nutritionally superior to rice and wheat, provide cheap protein, minerals like, calcium, iron, potassium, magnesium and zinc and $\mathrm{B}$-vitamins, especially niacin and $\mathrm{B}_{6}$ to poorest of the poor where the need for such ingredients is the maximum (Annesh, 2007). Hence, it is often considered as "poor man's cereal". On global basis small millets are cultivated on an area of 36.79 million ha with an annual production of 29.20 million tonnes indicating the productivity of $777 \mathrm{~kg} \mathrm{ha}^{-1}$. In india, they are cultivated on an area of 13.30 million ha with the production of 10.50 million tonnes with the productivity of $789 \mathrm{~kg}$ ha $^{-1}$ (Annesh, 2007). Important minor millets in India are finger millet (Eleusine coracana), Foxtail/Italian millet (Setaria italica), Kodomillet (Paspalum scrobiculatum), Common/Proso millet (Panicum miliaceum), Little millet (Panicum sumatrense), Barnyard/Sawa millet (Echino chloautilis). Among the minor millets, Kodo (Paspalum scrobiculatum L.) is one of the major food crops in tribal areas of the country. It is widely distributed in damp habitats across the tropics and subtropics of the World. It is known to have been grown in southern Rajasthan and Maharashtra for at least 3,000 years (Kajale, 1977; De Wet et al., 1983). This cereal is known also as varagu, kodo, harakaand arakalu.

Kodo millet is grown in diverse soils, varying rainfall regimes and in area widely differing in thermo and photoperiods. The resilience exhibited by this crop is helpful in adopting themselves to different ecological niches. The major constraints are (i) Kodomillet is grown on poor shallow and marginal soils under rainfed conditions, which is still grown in the hilly areas under shifting cultivation, (ii) The soils on which this crop is cultivated have low moisture retention capacity and (iii) seeds are often broadcast and it is cultivated under unfertilized and unweeded conditions. Weeds are the most competitors in their early growth stages than at later stages and hence the growth of crops was suffered and finally reduced the grain yield (Jacob and Syriac, 2005). Weeds grow profusely in the field and reduce crop yields drastically normally the loss in yield range between 15 to 20 per cent yet in severe cases the yield losses can be more than 50 per cent in rice depending upon the species and intensity of weeds (Mirza Hasanuzzama et al., 2009). Weed flora under transplanted condition is very much diverse and consists of grasses, sedges and broadleaved weeds causing yield reduction of rice crop upto 76 per cent (Govindra Singh et al., 2004).

Chemical method of weed control is effective to control the weeds economically. Now a days use of herbicides is gaining popularity due to their rapid effects and less cost involvement compared to traditional methods. Chemical method of weed control is economic and efficient method if applied at proper dose and stages (Kumar and Sharma, 2005). The use of herbicides offers selective control of weeds right from beginning, giving crop and advantage of good start and competitive superiority over weed (Saha, 2006).

Keeping these above said facts in consideration, the present investigation was carried out to study the effect of weed management on weed population, weed dry matter production, weed control efficiency and nutrient uptake by weeds; to study the effect of weed management on economics of transplanted kodo millet.

\section{Materials and Methods}

A field experiment was conducted at the Experimental Farm, Department of Agronomy, Faculty of Agriculture, Annamalai 
University, Annamalai Nagar, Tamil Nadu, India during Kharif season (June- October) 2014. The experimental farm is geographically located at $11^{\circ} 24^{\prime}$ North latitude and $79^{\circ}$ $44^{\prime}$ East longitude and at an altitude of $5.79 \mathrm{~m}$ above mean sea level in the southern part of India. The weather at Annamalai Nagar is moderately warm with hot summer months. The maximum temperature ranges from $28.1^{\circ} \mathrm{C}$ and $38.3^{\circ} \mathrm{C}$ with a mean of $33.7^{\circ} \mathrm{C}$, while the minimum temperature ranges from $18.9^{\circ} \mathrm{C}$ to $27.5^{\circ} \mathrm{C}$ with a mean of $23.2^{\circ} \mathrm{C}$. The mean annual rainfall received is $1600 \mathrm{~mm}$ with a distribution of $1000 \mathrm{~mm}$ during North East Monsoon, $400 \mathrm{~mm}$ during the South West Monsoon and $100 \mathrm{~mm}$ during hot weather period which is spread over 60 rainy days. The soil of the experimental field was clay with a $\mathrm{pH}$ of 7.9. The soil was low in available $\mathrm{N}$, medium in available $\mathrm{P}_{2} \mathrm{O}_{5}$ and high in available $\mathrm{K}_{2} \mathrm{O}$. The experiment was laid out in randomized block design with four replications involving sowing methods as main plot treatments comprised of transplanting, whereas weed management practices comprised of six treatments viz., Unweeded control, Hand weeding on $20^{\text {th }}$ and $40^{\text {th }}$ days after transplanting (DAT), Pre emergence application of Butachlor @ $1.5 \mathrm{~kg}$ a.i /ha on 3 DAT, Pre - emergence application of Pretilachlor @ $0.5 \mathrm{~kg}$ a.i/ ha on 3 DAT, Post - emergence application of 2, 4, D- Na Salt @ $0.75 \mathrm{~kg}$ a.i/ha on 20 DAT, Post emergence application of Bispyribac- Sodium @ $20 \mathrm{~g} / \mathrm{ha}$ on $20 \mathrm{DAT}$. The nursery bed was prepared by raising raised beds of size $3 \mathrm{~m}$ length and $1.5 \mathrm{~m}$ width and $15 \mathrm{~cm}$ height. The main field was ploughed at optimum moisture condition with tractor mounted mould board plough followed by rotovator to break clods to get a fine tilth. Field was irrigated before transplanting, then seedling was uprooted from the nursery on 20 days after sowing and transplanted in the main field by adopting the spacing of $15 \times 10 \mathrm{~cm}$. The crop was sown on June $22^{\text {nd }}$ during the Kharif season using kodo millet variety 'CO 3' at the seed rate of 10 $\mathrm{kg} / \mathrm{ha}$. The Kodomillet crop was fertilized with 44:22:0 kg of $\mathrm{N}, \mathrm{P}_{2} \mathrm{O}_{5}$ and $\mathrm{K}_{2} \mathrm{O} \mathrm{ha}^{-1}$ in the form of urea $(46 \% \mathrm{~N})$ and DAP $(18 \% \mathrm{~N}$ and $46 \% \mathrm{P}_{2} \mathrm{O}_{5}$ ) during the crop. The entire dose of $\mathrm{P}_{2} \mathrm{O}_{5}$ and half of the dose of $\mathrm{N}$ was applied as basal. The remaining half of $\mathrm{N}$ was top dressed in two equal splits at active tillering and flowering stage. The preemergence herbicides viz., butachlor and pretilachlor were sprayed with knapsack sprayer fitted with a flood-jet nozzle. The preemergence herbicides were sprayed on the third day after transplanting. The postemergence herbicide viz., 2, 4, D - Na salt and bispyribac- sodium were sprayed on the twenty days after transplanting. Herbicides were mixed with a calibrated amount of water and sprayed plot wise. In the plot where herbicides were not applied, hoeing and weeding was done by hand hoe with the help of manual labourers on 20 and 40 DAT after transplanting. Total weed counts were recorded on 30 and 60 DAT from four quadrats each of area $0.25 \mathrm{~m} 0.25 \mathrm{~m}$ fixed permanently in sampling area of each treatment and expressed in number of weeds $\mathrm{m}^{-2}$. The weed in the sample quadrats were collected from each plot separately on 30 and 60 DAT and roots were clipped off, oven dried at $80^{\circ} \mathrm{C} \pm 5^{\circ} \mathrm{C}$ for 48 hours, a constant weight obtained and expressed in $\mathrm{kg} \mathrm{ha}^{-}{ }^{1}$. Observations on weed control index, nutrient uptake by weed, growth, yield attributes, yield, nutrient uptake by crop and were recorded. Soil samples were collected at random from experimental fields, dried and ground for chemical analysis. Soil $\mathrm{pH}$ was determined by using a glass electrode $\mathrm{pH}$ meter (Jackson, 1973). The total N content of the soil was determined by Kjeldahl method (Jackson, 1973), available P by ascorbic acid and blue colour method (Watanabe and Olsen, 1965) and available $\mathrm{K}$ by flame photometer (Jackson, 1973). Concentrated nitric acid was used for digestion of plant samples. Total $\mathrm{P}$ 
concentration was determined by Vanadomolybdate yellow colour method (Jackson, 1973), K concentration by Flame photometer method (Jackson, 1973).

Data obtained from the experiment was analysed by using the technique of analysis of variance (ANOVA) and the difference between treatment means was tested for their statistical significance with appropriate critical difference (CD) at $5 \%$ level of probability (Gomez and Gomez, 1984).

\section{Results and Discussion}

\section{Weed observations}

Individual weed counts $\mathrm{m}^{-2}$ on 30 and 60 DAT

Weeds viz., Cyperus rotundus, Bergia capensis, Eclipta alba, Echinochloa colonum, and Leptochloa chinensis was observed in experimental plots. Weeds like Cyperus rotundus (47.33 per cent) and Bergia capensis (46.62 per cent) were occurring in major proportions among the total weeds and these were significantly influenced by the weed control treatments.

At 30 DAT, hand weeding on 20 and 40 DAT $\left(\mathrm{T}_{2}\right)$ recorded the least individual weed count of $1.37 \mathrm{~m}^{-2}$ of $C$. rotundus and $1.93 \mathrm{~m}^{-2}$ of B. capensis and the unweeded control $\left(\mathrm{T}_{1}\right)$ recorded the highest individual weed count $5.79 \mathrm{~m}^{-2}$ of $C$. rotundus and $5.88 \mathrm{~m}^{-2}$ of $B$. capensis, respectively (Table 1).

The data recorded on individual weed count $\mathrm{m}^{-2}$ on 60 DAT is furnished in Table 2. Hand weeding on 20 and 40 DAT $\left(\mathrm{T}_{2}\right)$ recorded the least individual weed count of $2.77 \mathrm{~m}^{-2}$ of $C$. rotundus and $2.62 \mathrm{~m}^{-2}$ of B. capensis on 60 DAT and the unweeded control $\left(\mathrm{T}_{1}\right)$ recorded the maximum individual weed count $8.58 \mathrm{~m}^{-2}$ of $C$. rotundus and $6.81 \mathrm{~m}^{-2}$ of $B$. capensis on 60 DAT.

\section{Total weed count $\mathrm{m}^{-2}$ on 30 and 60 DAT}

The data on total weed count $\mathrm{m}^{-2}$ on 30 and 60 DAT is furnished in Table 3. The total weed count was significantly influenced by the weed control treatment on 30and 60 DAT. Among the different weed control measures, hand weeding on 20 and 40 DAT $\left(\mathrm{T}_{2}\right)$ controlled most ofthe weeds and recorded the least total weed count of $7.63 \mathrm{~m}^{-2}$ and 13.58 $\mathrm{m}^{-2}$ on 30 and 60 DAT and the highest total weed count of $26.29 \mathrm{~m}^{-2}$ and $39.63 \mathrm{~m}^{-2}$ was recorded in unweeded control $\left(\mathrm{T}_{1}\right)$ on 30 and 60 DAT.

\section{Weed biomass $\left(\mathrm{kg} \mathrm{ha}^{-1}\right)$}

The data on weed biomass on 30 and 60 DAT are presented in Table 3. All the treatments significantly influenced the weed biomass on 30 and 60 DAT. Among the treatments, hand weeding on 20 and $40 \mathrm{DAT}\left(\mathrm{T}_{2}\right)$ was superior and recorded the lowest weed biomass of 4.83 $\mathrm{kg} \mathrm{ha}^{-1}$ and $7.79 \mathrm{~kg} \mathrm{ha}^{-1}$ on 30 and 60 DAT and the maximum weed biomass was recorded in unweeded control $\left(\mathrm{T}_{1}\right) 15.79 \mathrm{~kg} \mathrm{ha}^{-1}$ and $20.81 \mathrm{~kg} \mathrm{ha}^{-1}$ on 30 and 60 DAT, respectively.

\section{Weed control index (\%)}

The computed data on weed control index recorded on 30 and 60 DAT are present in Table 3. Among the various treatments tested, hand weeding on 20 and 40 DAT $\left(\mathrm{T}_{2}\right)$ recorded the highest WCI of 69.41 and 62.56 per cent on 30 and 60 DAT, respectively.

This was followed by application of post emergence herbicide bispyribac sodium @20 $\mathrm{g} \mathrm{ha}^{-1}$ on $20 \mathrm{DAT}\left(\mathrm{T}_{6}\right)$ recorded the highest WCI of 64.21 and 58.76 per cent on 30 and 60 DAT, respectively.

\section{Nutrient removal by weeds $\left(\mathrm{kg} \mathrm{ha}^{-1}\right)$}

The data on nutrient removal by weeds are presented in Table 4. 
Int.J.Curr.Microbiol.App.Sci (2018) 7(11): 824-831

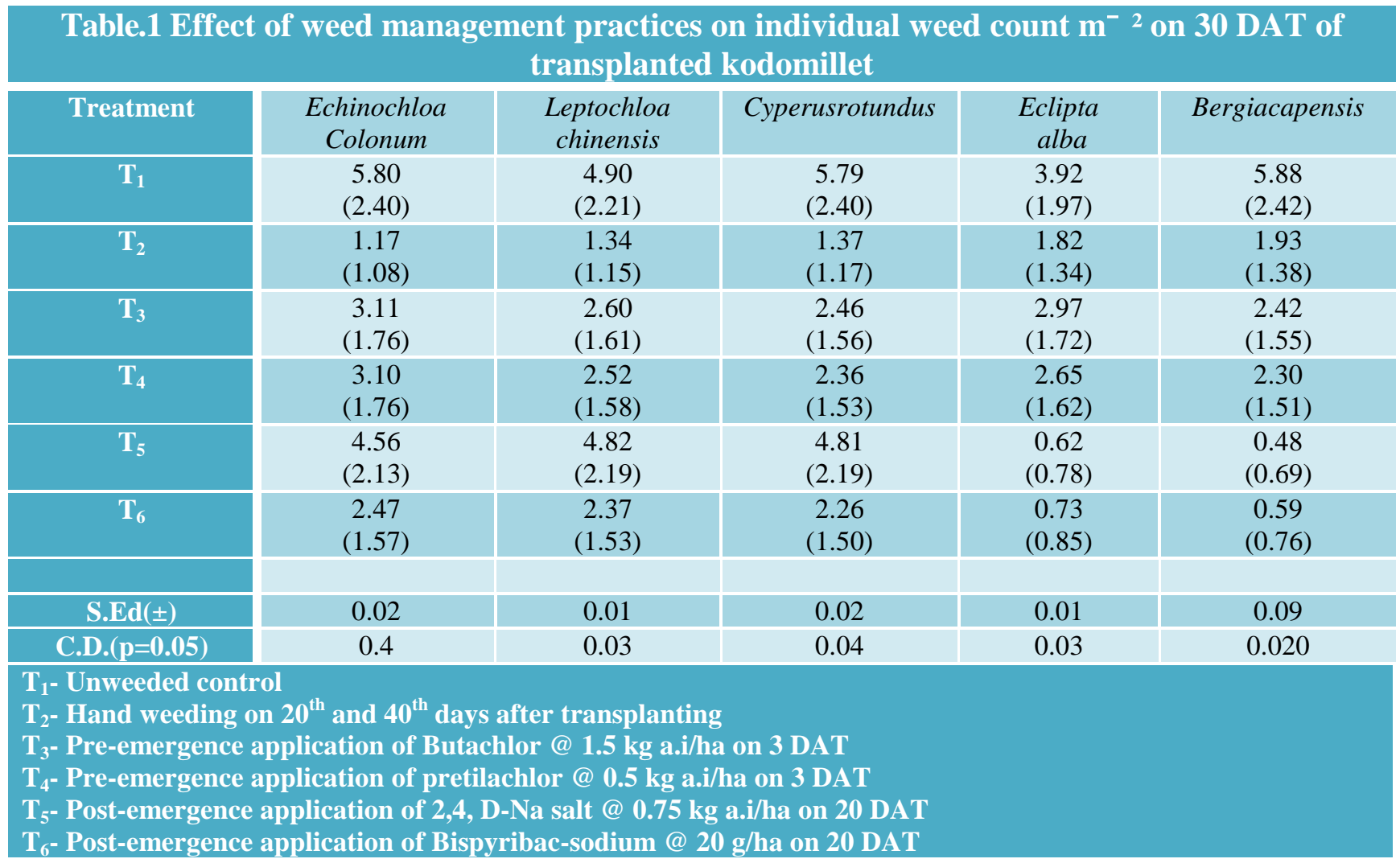

\begin{tabular}{|c|c|c|c|c|c|}
\hline Treatment & $\begin{array}{c}\text { Echinochloa } \\
\text { Colonum }\end{array}$ & $\begin{array}{l}\text { Leptochloa } \\
\text { chinensis }\end{array}$ & Cyperusrotundus & $\begin{array}{c}\text { Eclipta } \\
\text { alba }\end{array}$ & Bergiacapensis \\
\hline $\mathrm{T}_{1}$ & $\begin{array}{c}8.85 \\
(2.97)\end{array}$ & $\begin{array}{c}7.97 \\
(2.82)\end{array}$ & $\begin{array}{c}8.58 \\
(2.92)\end{array}$ & $\begin{array}{c}7.42 \\
(2.72)\end{array}$ & $\begin{array}{c}6.81 \\
(2.60)\end{array}$ \\
\hline $\mathbf{T}_{2}$ & $\begin{array}{c}2.81 \\
(1.67)\end{array}$ & $\begin{array}{c}2.94 \\
(1.71)\end{array}$ & $\begin{array}{c}2.77 \\
(1.66)\end{array}$ & $\begin{array}{c}2.44 \\
(1.56)\end{array}$ & $\begin{array}{c}2.62 \\
(1.61)\end{array}$ \\
\hline $\mathbf{T}_{3}$ & $\begin{array}{c}4.52 \\
(2.12)\end{array}$ & $\begin{array}{c}3.26 \\
(1.80)\end{array}$ & $\begin{array}{c}3.65 \\
(1.91)\end{array}$ & $\begin{array}{c}3.42 \\
(1.84)\end{array}$ & $\begin{array}{c}3.35 \\
(1.83)\end{array}$ \\
\hline $\mathbf{T}_{4}$ & $\begin{array}{c}4.31 \\
(2.07)\end{array}$ & $\begin{array}{c}3.23 \\
(1.79)\end{array}$ & $\begin{array}{c}3.35 \\
(1.83)\end{array}$ & $\begin{array}{c}3.14 \\
(1.77)\end{array}$ & $\begin{array}{c}3.15 \\
(1.77)\end{array}$ \\
\hline$T_{5}$ & $\begin{array}{c}6.50 \\
(2.54)\end{array}$ & $\begin{array}{c}5.72 \\
(2.39)\end{array}$ & $\begin{array}{c}5.51 \\
(2.34)\end{array}$ & $\begin{array}{c}1.49 \\
(1.22)\end{array}$ & $\begin{array}{c}1.58 \\
(1.25)\end{array}$ \\
\hline$T_{6}$ & $\begin{array}{c}3.27 \\
(1.80)\end{array}$ & $\begin{array}{c}3.19 \\
(1.78)\end{array}$ & $\begin{array}{c}3.32 \\
(1.82)\end{array}$ & $\begin{array}{c}2.64 \\
(1.62)\end{array}$ & $\begin{array}{c}2.75 \\
(1.65)\end{array}$ \\
\hline S.Ed( $( \pm)$ & 0.02 & 0.03 & 0.75 & 0.01 & 0.03 \\
\hline C.D. $(p=0.05)$ & 0.4 & 0.06 & 1.68 & 0.03 & 0.07 \\
\hline \multicolumn{6}{|c|}{$\begin{array}{l}\mathrm{T}_{1^{-}} \text {Unweeded control } \\
\mathrm{T}_{2^{-}} \text {Hand weeding on } 20^{\text {th }} \text { and } 40^{\text {th }} \text { days after transplanting } \\
\mathrm{T}_{3} \text { - Pre-emergence application of Butachlor @ } 1.5 \mathrm{~kg} \text { a.i/ha on } 3 \text { DAT } \\
\mathrm{T}_{4^{-}} \text {Pre-emergence application of pretilachlor @ } 0.5 \mathrm{~kg} \text { a.i/ha on } 3 \mathrm{DAT} \\
\mathrm{T}_{5^{-}} \text {Post-emergence application of } 2,4, \mathrm{D}-\mathrm{Na} \text { salt @ } 0.75 \mathrm{~kg} \text { a.i/ha on } 20 \mathrm{DAT} \\
\mathrm{T}_{6} \text { - Post-emergence application of Bispyribac-sodium @ } 20 \mathrm{~g} / \mathrm{ha} \text { on } 20 \mathrm{DAT}\end{array}$} \\
\hline
\end{tabular}


Int.J.Curr.Microbiol.App.Sci (2018) 7(11): 824-831

Table.3 Weed management practices on total weed count $\mathrm{m}^{-2}$ on 30 and 60 DAT, weed biomass $\left(\mathrm{kg} \mathrm{ha}^{-1}\right)$ and weed control index $(\%)$ in transplanted kodomillet

\begin{tabular}{|c|c|c|c|c|c|c|}
\hline \multirow[b]{2}{*}{ Treatment } & \multirow{2}{*}{$\begin{array}{l}\text { Total weed } \\
\text { count } \mathrm{m}^{-2} \text { on } \\
30 \text { DAT }\end{array}$} & \multirow{2}{*}{$\begin{array}{l}\text { Total weed } \\
\text { count } \mathrm{m}^{-2} \text { on } \\
60 \mathrm{DAT}\end{array}$} & \multicolumn{2}{|c|}{ Weed biomass $\left(\mathrm{kg} \mathrm{ha}^{-1}\right)$} & \multicolumn{2}{|c|}{ Weed control index (\%) } \\
\hline & & & $30 \mathrm{DAT}$ & $60 \mathrm{DAT}$ & $30 \mathrm{DAT}$ & 60 DAT \\
\hline$\overline{T_{1}}$ & $\begin{array}{l}26.29 \\
(5.12)\end{array}$ & $\begin{array}{l}39.63 \\
(6.29)\end{array}$ & 15.79 & 20.81 & - & - \\
\hline$\overline{T_{2}}$ & $\begin{array}{l}7.63 \\
(2.76)\end{array}$ & $\begin{array}{l}13.58 \\
(3.68)\end{array}$ & 4.83 & 7.79 & $\begin{array}{l}69.41 \\
(8.33)\end{array}$ & $\begin{array}{l}62.56 \\
(7.91)\end{array}$ \\
\hline$\overline{T_{3}}$ & $\begin{array}{l}13.56 \\
(3.68)\end{array}$ & $\begin{array}{c}18.2 \\
(4.26)\end{array}$ & 8.51 & 11.95 & $\begin{array}{l}46.10 \\
(6.79)\end{array}$ & $\begin{array}{l}42.57 \\
(6.52)\end{array}$ \\
\hline $\mathbf{T}_{4}$ & $\begin{array}{l}12.93 \\
(3.59)\end{array}$ & $\begin{array}{l}17.18 \\
(4.14)\end{array}$ & 7.64 & 10.95 & $\begin{array}{l}51.61 \\
(7.18)\end{array}$ & $\begin{array}{l}47.38 \\
(6.88)\end{array}$ \\
\hline$T_{5}$ & $\begin{array}{l}15.29 \\
(3.91)\end{array}$ & $\begin{array}{c}20.8 \\
(4.56)\end{array}$ & 9.34 & 13.80 & $\begin{array}{l}40.84 \\
(6.39)\end{array}$ & $\begin{array}{l}33.68 \\
(5.80)\end{array}$ \\
\hline$\overline{T_{6}}$ & $\begin{array}{c}8.42 \\
(2.90)\end{array}$ & $\begin{array}{l}15.17 \\
(3.89)\end{array}$ & 5.65 & 8.58 & $\begin{array}{l}64.21 \\
(8.01)\end{array}$ & $\begin{array}{l}58.76 \\
(7.66)\end{array}$ \\
\hline S.Ed( $( \pm)$ & 0.02 & 0.05 & 0.02 & 0.19 & 0.93 & 0.64 \\
\hline C.D. $(p=0.05)$ & 0.05 & 0.1 & 0.05 & 0.43 & 2.07 & 1.42 \\
\hline \multicolumn{7}{|c|}{$\begin{array}{l}\mathrm{T}_{1} \text { - Unweeded control } \\
\mathrm{T}_{2} \text { - Hand weeding on } 20^{\text {th }} \text { and } 40^{\text {th }} \text { days after transplanting } \\
\mathrm{T}_{3} \text { - Pre-emergence application of Butachlor @ } 1.5 \mathrm{~kg} \text { a.i/ha on } 3 \mathrm{DAT} \\
\mathrm{T}_{4} \text { - Pre-emergence application of pretilachlor @ } 0.5 \mathrm{~kg} \mathrm{a} \text {.i/ha on } 3 \mathrm{DAT} \\
\mathrm{T}_{5} \text { - Post-emergence application of } 2,4, \mathrm{D}-\mathrm{Na} \text { salt @ } 0.75 \mathrm{~kg} \text { a.i/ha on } 20 \mathrm{DAT} \\
\mathrm{T}_{6} \text { - Post-emergence application of Bispyribac-sodium @ } 20 \mathrm{~g} / \mathrm{ha} \text { on } 20 \mathrm{DAT}\end{array}$} \\
\hline
\end{tabular}

Table.4 Weed management practices on nutrient removal (NPK) by weeds (kg ha ${ }^{-1}$ ) and economic analysis of transplanted kodomillet

\begin{tabular}{|c|c|c|c|c|c|c|c|}
\hline \multirow[t]{2}{*}{ Treatment } & \multicolumn{3}{|c|}{$\begin{array}{l}\text { Nutrient removal (NPK) by } \\
\text { weeds }\left(\mathrm{kg} \mathrm{ha}^{-1}\right)\end{array}$} & \multicolumn{4}{|c|}{ Economic analysis } \\
\hline & $\mathrm{N}$ & $\mathrm{P}$ & K & $\begin{array}{c}\text { Cost of } \\
\text { cultivation } \\
\left(\mathrm{ha}^{-1}\right)\end{array}$ & $\begin{array}{l}\text { Gross income } \\
\left(\mathrm{ha}^{-1}\right)\end{array}$ & $\begin{array}{c}\text { Net } \\
\text { income } \\
\left(\mathrm{ha}^{-1}\right)\end{array}$ & $\begin{array}{c}\text { Return } \\
\text { Rupee }^{-} \mathbf{1}\end{array}$ \\
\hline $\mathrm{T}_{1}$ & 26.41 & 14.24 & 21.91 & 14588 & 18694 & 4106 & 1.28 \\
\hline $\mathbf{T}_{2}$ & 15.64 & 7.64 & 13.94 & 25749 & 59017 & 33268 & 2.29 \\
\hline $\mathbf{T}_{3}$ & 22.18 & 11.62 & 18.69 & 32845 & 45670 & 12825 & 1.39 \\
\hline $\mathbf{T}_{4}$ & 19.87 & 11.31 & 17.32 & 33323 & 51202 & 17879 & 1.53 \\
\hline $\mathbf{T}_{5}$ & 24.15 & 13.86 & 20.32 & 21894 & 29887 & 7993 & 1.36 \\
\hline $\mathrm{T}_{6}$ & 17.55 & 9.56 & 15.52 & 34011 & 82190 & 48179 & 2.41 \\
\hline S.Ed( \pm$)$ & 0.82 & 0.16 & 0.55 & & & & \\
\hline C.D. $(p=0.05)$ & 1.72 & 0.34 & 1.17 & & & & \\
\hline \multicolumn{8}{|c|}{$\begin{array}{l}\mathrm{T}_{1} \text { - Unweeded control } \\
\mathrm{T}_{2} \text { - Hand weeding on } 20^{\text {th }} \text { and } 40^{\text {th }} \text { days after transplanting } \\
\mathrm{T}_{3} \text { - Pre-emergence application of Butachlor @ } 1.5 \mathrm{~kg} \text { a.i/ha on } 3 \mathrm{DAT} \\
\mathrm{T}_{4} \text { - Pre-emergence application of pretilachlor @ } 0.5 \mathrm{~kg} \mathrm{a} . \mathrm{i} / \mathrm{ha} \text { on } 3 \mathrm{DAT} \\
\mathrm{T}_{5} \text { - Post-emergence application of } 2,4, \mathrm{D}-\mathrm{Na} \text { salt } @ 0.75 \mathrm{~kg} \text { a.i/ha on } 20 \mathrm{DAT} \\
\mathrm{T}_{6} \text { - Post-emergence application of Bispyribac-sodium @ } 20 \mathrm{~g} / \mathrm{ha} \text { on } 20 \mathrm{DAT}\end{array}$} \\
\hline
\end{tabular}


Among the various herbicide tested, hand weeding on 20 and 40 DAT $\left(\mathrm{T}_{2}\right)$ recorded the lowest nutrient removal by weeds of 15.64, 7.64 and $13.94 \mathrm{~kg} \mathrm{~N}, \mathrm{P}_{2} \mathrm{O}_{5}$ and $\mathrm{K}_{2} \mathrm{O}$ $\mathrm{ha}^{-1}$ and the maximum nutrient removal by weeds were recorded under unweeded control $\left(\mathrm{T}_{1}\right)$ with the values of $26.41,14.24$ and $21.91 \mathrm{~kg} \mathrm{~N}, \mathrm{P}$ and $\mathrm{K} \mathrm{ha}^{-1}$, respectively.

\section{Economics}

\section{Net income and return rupee ${ }^{-1}$ invested}

The economic analysis of different weed management practices in transplanted kodomillet during kharif season is presented in Table 4. Application of post emergence herbicide bispyribac sodium @ $20 \mathrm{~g} \mathrm{ha}^{-1}$ on 20 DAT $\left(\mathrm{T}_{6}\right)$ registered the highest net income of Rs $48179 \mathrm{ha}^{-1}$ and return rupee invested of 2.41.This was followed by hand weeding twice on 20 and 40 DAT $\left(\mathrm{T}_{2}\right)$ recorded the net income of Rs $33268 \mathrm{ha}^{-1}$ and return rupee ${ }^{-1}$ invested of Rs 2.29. Unweeded control $\left(T_{1}\right)$ was recorded the least net income of $7206 \mathrm{ha}^{-1}$ and return rupee $^{-1}$ invested of 1.49 .

\section{Weed observations}

Experimental field comprised of Cyperus rotundus, Bergia capensis, Eclipta alba, Echinochloa colonum and Leptochloa chinensis. However, only two weeds viz. Cyperus rotundus and Bergia capensis constituted greater proportions of weed flora in the experimental plots. The other weeds occurred only in negligible proportions and their occurrence was also rare. The weed control treatments exert significant influence over the individual weed count, total weed count, weed biomass, WCI and nutrient removal by weeds. Among the different weed control practices compared, hand weeding twice at 20 and 40 DAT significantly superior for reducing the grasses, sedges and boardleaved weed density and dry weight than the other herbicides, hence increased the yield of crop. This might be due to the effective control of weed seed emergence and establishment initially and depleting the soil seed reserves and the late emerged weeds can be controlled through the hand weeding twice on 20 and 40 DAT. Similar results were reported by Chauhan et al., (2013). Highest weed count, weed biomass and nutrient removal by weed were recorded under unweeded control. This might be due to weed population and may be attributed to uninterrupted weed growth throughout the crop season. Similar results were also reported by Ram et al., (2003) in pearlmillet.

\section{Nutrient uptake}

Weed management practices were significantly influenced on nutrient uptake (NPK) by the crop. The higher nutrient uptake was recorded in hand weeding at 20 and 40 DAT. Whereas the lowest uptake by crop was recorded in unweeded control. The significant variation in nutrient uptake by crop might be due to better control of weeds that enhanced growth and development of the crop. Thus, the reduced weed competition for nutrients favored the crop against weeds resulting in increased nutrient uptake. These results are in agreement with the finding of Amare et al., (2014) in wheat.

\section{Economics}

Improved crop performance through efficient and cheaper weed control was responsible for highest net income with lesser cost of cultivation and highest return rupee ${ }^{-1}$ invested in treatment offered better weed control with the application of post emergence bispyribac sodium @ $20 \mathrm{~g} / \mathrm{ha}$ on $3 \mathrm{DAT}$. This was followed by hand weeding twice on 20 and 40 DAT. Unweeded control treatment registered the lowest net income and return rupee ${ }^{-1}$ invested due to poor grain yield as it 
experienced severe weed competition throughout the crop growth period. These are in line with the earlier reports of Hussain et al., (2008).

It can be concluded that application of bispyribac sodium @ $20 \mathrm{~g} \mathrm{ha}^{-1}$ on 20 DAT holds immense potentiality to control the all types of weeds boost the productivity and profitability of transplanted kodomillet.

\section{References}

Amare, T., Sharma, J.J. and Zewdie, K. (2014). Effect of weed control methods on weeds and wheat (Triticum aesticum L.) yield. J. Agril Res., 2(3): 124-128.

Annesh, D.N. (2007). Production and marketing of underutilized millets in Karnataka. An economic analysis. Ph.D. Thesis submitted to the University of Agricultural Sciences, Dharwad.

Chauhan, P.S., Jha, A.K. and Soni, M. (2013). Efficacy of chlorimuron-ethyl against weeds in transplanted rice. Ind. J. Weed. Sci., 45(2); 135-136.

De Wet, J. M. J., Prasada Rao, K.E., Mengesha, M.H. and Brink, D.E. (1983). Diversity in Kodo Millet, Paspalum scrobiculatum L. Economic Botany, 37(2): 159-163.

Gomez, K.A. and Gomez, A.A. (1984).Statistical Procedure for Agricultural Research, 2nd Edition. Wiley Interscience Pub., John Wiley and Sons, New York. pp. 628.

Hasanuzzama, M., Ali, M.H., Alam, M.M., Akther, M. and Alam, K.F. (2009). Evaluation of Pre emergence Herbicide and Hand Weeding on the Weed Control Efficiency and Performance of Transplanted Aus Rice. AmericanEurasian J. Agron., 2(3): 138-143.
Hussain, S.M., Ramzan, M.A. and Aslam, M. (2008). Weed management in direct seeded rice. J.Anim.PI.Sci., 18(2-3).

Jackson, M.L. (1973a). Soil chemical analysis. Prentice Hall of India Inc., New Delhi, p. 170.

Jackson, M.L. (1973b). Soil chemical analysis. Prentice Hall of India Pvt. Ltd. New Delhi, p. 498.

Jacob, D. and Syriac, E.K. (2005). Performance of transplanted scanted rice (Oryza sativa L.) under different spacing and weed management regimes in Southern Kerana. J. Trop. Africa, 43(1):71-73.

Kajale, M.P. (1977). Ancient grains from excavations at Nevassa, Maharashtra. Geophytology, 7: 98-106.

Kumar, M. and Sharma, G. (2005). Effect of herbicides alone and in combination on direct seeds rice. Indian J. Weed Sci., 37(3\&4): 197-201.

Ram, B., Choudhary, G.R., Jat, A.S. and Jat, M.L. (2003). Effect of integrated weed management and intercropping system on growth and yield of pearlmillet (Pennisutum glaucum). Ind. J. Agron., 48(4) 254-258.

Saha, S. (2006). Comparative study on efficacy of sulfonyl urea herbicides and traditional recommended herbicides in transplanted rice. Indian J. Agron., 51(4):304-306.

Singh, G., Singh, V.P. and Singh, M. (2004). Effect of almix and butachlor along and in combinations on transplanted rice and associated weeds. Indian J. Weeds Sci., 36(1\&2): 64-67.

Watanabe, I. and Olsen, S.R. (1965). Test of an ascorbic acid method for determining phosphorus in water and $\mathrm{NaHCO}_{2}$ extract from the soil. Soil Sci. Amer. Proc., 29:677-678.

\section{How to cite this article:}

Yendrembam Bebila Chanu, S. Jawahar, K. Nandini Devi, Priyanka Irungbam and Jamkhogin Lhungdim. 2018. To Study the Effect of Weed Observation Practices in Transplanted Kodomillet (Paspalum scrobiculatum L.). Int.J.Curr.Microbiol.App.Sci. 7(11): 824-831. doi: https://doi.org/10.20546/ijcmas.2018.711.097 